This is an author produced version of a paper published in Agribusiness.

This paper has been peer-reviewed and is proof-corrected, but does not include the journal pagination.

Citation for the published paper:

Feng, Li, Friis, Anna \& Nilsson, Jerker. (2016) Social Capital among

Members in Grain Marketing Cooperatives of Different Sizes. Agribusiness.

Volume: 32, Number: 1, pp 113-126.

http://dx.doi.org/10.1002/agr.21427.

Access to the published version may require journal subscription.

Published with permission from: Wiley.

Standard set statement from the publisher:

"This is the accepted version of the following article: Feng, L., Friis, A. and Nilsson, J. (2016), Social Capital among Members in Grain Marketing Cooperatives of

Different Sizes. Agribusiness, 32: 113-126. doi: 10.1002/agr.21427, which has been published in final form at

http://onlinelibrary.wiley.com/doi/10.1002/agr.21427/abstract."

Epsilon Open Archive http://epsilon.slu.se 


\title{
Social Capital among Members in Grain Marketing Cooperatives of Different Sizes
}

\author{
Article published in Agribusiness. An International Journal, Volume 32 (1), 113-126 \\ (2016). DOI: 10.1002/agr.21427 \\ Li Feng \\ Department of Economics, Swedish University of Agricultural Sciences, Uppsala, \\ Sweden.E-mail: fengli8386@gmail.com
}

\author{
Anna Friis \\ Landshypotek Bank, Uppsala, Sweden. E-mail: anna.friis@landshypotek.se \\ Jerker Nilsson \\ Department of Economics, Swedish University of Agricultural Sciences, Uppsala, \\ Sweden.E-mail: Jerker.Nilsson@slu.se
}

\begin{abstract}
According to social capital theory, small cooperatives with simple business operations have more social capital in their membership than large, complex cooperatives. The geographical and social proximity among members, and between members and leadership, fosters social capital. This proposition is investigated empirically using data from member surveys in three Swedish farm supply and grain marketing cooperatives that vary greatly in size, from about 36,000 to 1600 and 150 members. The findings strongly support the view that the smaller the cooperative, the higher the social capital, expressed in terms of members' involvement, trust, satisfaction, and loyalty. [EconLit citations: A130; P130; Q130]
\end{abstract}

\section{INTRODUCTION}

This study examines the relationship between cooperative size and the amount of social capital in the cooperative membership. A cooperative is an enterprise collectively owned and democratically governed by a group of patrons. There are solid arguments in the literature for the establishment of cooperative organizations (Staatz, 1987; Ollila, 1989). Such organizations reduce the members' transaction costs in cases where the markets are characterized by skewed power balances and uncertainties. Cooperatives have traditionally a large share of the equity as unallocated capital, built up from retained profits over the years. The control is by the principle of one member, one vote. Equal treatment of the members is essential. These attributes are socially attractive, which means that traditionally organized cooperative often appeal to a large number of farmers and hence obtain large volumes of goods to process (Sexton, 1986; Nilsson, 1998). Economies of scale can thereby be achieved, further contributing to the economic benefits for members. These arguments explain why cooperative organizations have become not only numerous and strong in many sectors of the economy in many countries, but also very large.

Many cooperatives have expanded through horizontal and vertical integration, often as a response to increasing competition. The consequence of complex business operations and large, heterogeneous memberships is that the members' support to their cooperatives is fading (Brazda 
\& Schediwy, 1989; Fulton \& Hueth, 2009). As a result, members' control of cooperatives has become weaker, i.e., the agency costs have risen (Harte, 1997; Lang \& Fulton, 2004; Lamprinakis \& Fulton, 2011). Poor member control may also deplete the ability of cooperatives to reduce transaction costs for their members.

The cooperatives' development towards large size might have led to less member involvement, less trust within the membership, less satisfaction, and less member loyalty. To the extent that a cooperative enjoys involvement, trust, satisfaction and loyalty from its membership it has valuable assets, which may be expressed in terms of social capital. Hence it may be supposed that large cooperatives have less social capital in the memberships than smaller cooperatives. The aim of this study is to explore differences in social capital in the membership of cooperatives offering the same types of services to their members, but differing in terms of size and complexity.

The relationship between the social capital that cooperatives enjoy in their membership and the size of cooperatives has received limited awareness by previous research as well as by decision-makers within cooperatives. Farmer-members have been assumed to choose their business partners on the basis of price, service, and other factors affecting the profitability of their farm enterprises (Karantininis \& Zago, 2001). Hence there have been financial arguments for expanding cooperatives, offering farmers better prices, etc. A problem is that thereby the balance between the financial side of cooperative business and the social side has been disturbed. Members patronize a cooperative not only for monetary benefits, but also for sociopsychological reasons. The farmers may appreciate better economic terms but they may consider it problematic that their cooperative has become so large and so complex that they do no longer feel a strong connection to it. For the decision-makers of the cooperative each decision about increasing horizontal and vertical integration may be small, but many small steps may over time have large consequences for the social capital within the membership (Nilsson, Svendsen \& Svendsen, 2012).

It is likely that cooperatives that are large in terms of membership, revenues, etc. are also complex as regards downstream and upstream operations, internationalization, membership heterogeneity, etc. Large and small cooperatives tend to differ also in terms of financial structure, governance, and member relations. For that reason, the expressions "large" and "small" are used here though they may represent also other organizational attributes.

The paper is organized as follows. Section 2 provides a theoretical discussion about how the size of cooperatives affects the amount of social capital in their membership, concluding with four hypotheses. The design of the empirical study is described in Section 3, while Section 4 reports the results obtained from statistical computations based on the data. The validity of the findings is discussed in Section 5 and conclusions are drawn in Section 6.

\section{THEORETICAL FRAMEWORK}

\subsection{Social capital}

Social capital concerns social ties between humans and within groups of people, including organizations and even society at large. The fact that the concept of social capital may be applied at different levels of the social hierarchy means that various definitions have been proposed. The present study focuses on social capital at the organizational level.

According to Bourdieu (1986, p. 243), social capital is "made up of social obligations ('connections'), which is convertible, in certain conditions, into economic capital and may be institutionalized in the form of a title of nobility". Woolcock (1998, p. 153) defines social 
capital as "the information, trust, and norms of reciprocity inherent in one's social networks". Both definitions are applicable in the present study.

Social capital is as important to interpersonal behaviors, business decisions, and government actions as financial capital. With low trust, much decision-making is difficult. Investors would scarcely buy assets if they do not believe that their suppliers would actually deliver the goods, if they could not reduce the labor force's inclination to cheat, if they could not trust the country's judicial system, etc. Trust reduces the transaction and agency costs in interpersonal and organizational settings. It decreases the costs to individuals and organizations of insuring themselves against deceitful behavior by their partners, both in social life and in business relations (Nilsson, Svendsen \& Svendsen, 2012). Trust can be higher in some specific small and large social groups than in others, for example in families, neighborhoods, clubs, workplaces, and religious communities.

\subsection{Social capital in cooperative memberships}

Social capital is highly relevant in a cooperative context. If a cooperative society is to enjoy member satisfaction and member loyalty, it must be governed by the members themselves, i.e., there must be some form of social relations within the membership (Hakelius, 1996; Borgen, 2001). There must be trust in the sense that the members should have at least some confidence in one another, in the elected representatives, and in the management (Morrow, Hansen \& Pearson, 2004; Nilsson, Kihlén \& Norell, 2009). A successful cooperative presupposes that members involve themselves in the governance of the cooperative (Österberg \& Nilsson, 2009), i.e., they consider the cooperative to be important for them.

There are theoretical arguments regarding whether larger or smaller cooperatives have more social capital within their memberships. As cooperatives are rooted in popular movements, characterized by social idealism and active participation, small cooperatives have better prospects for the involvement of members, who feel proximity to each other and to the business operations. Large cooperatives may, on the other hand, be more efficient, thereby obtaining more appreciation by their members.

The pooling of members' products and inputs in cooperatives normally leads to lower average costs (Staatz, 1987). Hence, due to economies of scale, cooperatives with substantial horizontal integration may be able to pay a higher price for their members' deliveries and offer lower prices for farm inputs. Likewise, cooperatives with far-reaching vertical integration may use the profits from upstream and downstream activities to support the members financially. Large cooperatives may also have market power and hence the revenues may rise, so the prices offered to members may be better. Furthermore, large cooperatives are more likely to recruit highly professional and competent managers. This reasoning implies that large, i.e. horizontally and vertically integrated cooperatives may enjoy more member support. If so, the members may become more involved in governing the cooperative, more loyal in trading with the cooperative, more willing to invest capital, etc. Such member behaviors should lead to better business results, better prices, higher satisfaction, and so on, ceteris paribus, which is to say that virtuous circles will arise.

However, there are also counterarguments. The core is the notion of vaguely defined property rights (VDPRs). VDPR problems may evolve when cooperatives are "... becoming increasingly complex in their organizational structure" (Cook, 1995, p. 1156). Under these circumstances, these problems lead to fading member involvement, i.e. the social capital within the membership suffers.

It is rational for a member to be a free-rider in relation to other members. The members' horizon is limited to their remaining membership period and therefore the cooperative's investment portfolio will not be optimal for the totality of members. No matter how skilled the 
leadership, it will have difficulties in making decisions to the benefit of the entire membership. The members will not be capable of controlling the leadership, or encouraged to do so.

The problems may be expected to be more serious under certain conditions (Hansmann, 1996; Nilsson, 2001; Hendrikse \& Feng, 2013). One is when the cooperative has a large amount of unallocated capital so the members have limited personal investments in the cooperative. Another is when the cooperative's operations are not directly related to the members' operations so the members have difficulties to understand and feel less involved. VDPR problems are also more likely when the membership is heterogeneous and large whereby members more often try to free-ride. A common denominator is that there is a sense of anonymity within the membership, which is an expression of poor social capital.

While agency problems exist in all organizations where ownership and control are separated, they are larger in collectively structured organizations, among them cooperatives. As the leaders of investor-owned firms are disciplined by the capital market, it does not matter that the ownerships are anonymous bodies. There is no market mechanism for the equity capital of collectively owned and run cooperatives, so they are dependent on member control to discipline the leadership. Well-functioning member control requires social capital within the membership.

Cooperative problems are well documented in the literature. Already in 1911, the German sociologist Michels (2001 [1911]) coined the concept “The Iron Law of Oligarchy” meaning that it is impossible to retain member influence and member involvement in an organization working for the betterment of a large group of persons as this organization expands. It is unavoidable that a powerful clique will come to control the organization. This elite will have an interest in the organization's survival, regardless of the interests of the members.

Other observers have also expressed a critical view of the development of traditional cooperatives as they grow large:

In the development of Finnish cooperation a 'decisive moment', strategic turning point, comes in its history when the pioneering forces are replaced by the maintaining forces. At this moment there is the danger that the movement will become bureaucratized and an end in itself. (Ilmonen, 1992, p. 5)

In the later stages of the life cycle, the aspirations of the managers, rather than those of the farmers, are realised. (Hind, 1999, p. 536)

The development towards large cooperatives, characterized by low social capital, has been analyzed by several scholars. The core of the explanations is that intensifying competition induces many cooperatives to merge into increasingly large and complex firms (Hogeland, 2006; Nilsson, Svendsen \& Svendsen, 2012). The cooperatives are then no longer steered by social values and member connectedness, as they come to mirror the structures and the strategies of the competing investor-owned firms. Bager (1996) uses population ecology to explain why cooperatives lose their cooperative identity as they grow large. Cooperatives once constituted a sub-population of formal organizations within an economy and an industry, but they gradually merge into the dominant sub-population of investor-owned firms.

In conclusion, there are prevailing theoretical arguments for the proposition that large cooperatives have lower social capital within their membership. The next section reviews empirical studies about social capital in cooperative memberships.

\subsection{Empirical studies}

Numerous empirical studies report members' view of their cooperatives (Cain, Toensmeyer \& Ramsey, 1989; Jensen, 1990; Misra, Carley \& Fletscher, 1993; Klein, Richards \& Walburger, 1997; Gray \& Kraenzle, 1998; Richards, Klein \& Walburger, 1998: Hansen, Morrow \& Batista, 
2002; Lind \& Åkesson, 2005; Zeuli \& Betancor, 2005; James \& Sykuta, 2006; Bhuyan, 2007; Barbaud-Didier, Henninger \& El Akremi, 2012). The variables used in these studies comprise a large variety of socio-psychological constructs such as attitudes, knowledge, preferences, solidarity, and loyalty, which are related to social capital. In particular, several studies have focused specifically on members' trust in their cooperative and in its leadership.

In contrast, the size variable is seldom seen in studies of cooperative members' social capital. While some studies include the size of the farmers' operation (Bravo-Ureta \& Lee, 1988; Burt \& Wirth, 1990; Wadsworth, 1991), only a few researchers state that their sample of respondents originates from a cooperative of a specific size or membership number (Fulton \& Adamowicz, 1993). However, those researchers do not analyze the importance of the organizational size.

Only a few empirical studies present conclusions concerning the importance of cooperative size for the members' social capital and related variables. In a survey concerning members' perceived trust and disagreements, James and Sykuta (2005) find a positive connection to the degree of homogeneity of member interests, which is a concept linked to the size of the membership. Based on a survey of the members of one large cooperative, Nilsson, Kihlén and Norell (2009) conclude that the reason for poor member satisfaction, involvement, and trust is that the cooperative in question is very large. Two studies cover members' views of cooperatives of different sizes, although both are limited to a specific aspect, namely members' readership of the annual reports of their cooperative (Gaurwitsch \& Nilsson, 2010; Nilsson \& Svendsen, 2011). Both studies are based on member surveys, within two and five cooperative memberships, respectively. The findings indicate that the larger the cooperative, the less members care about keeping themselves informed about the cooperative and its governance.

\subsection{Hypotheses}

The previous subsections lead to the general proposition that a smaller cooperative has more social capital among its membership. Four indicators of social capital, all of which are often used in studies of cooperative memberships, are identified for this general proposition to be investigated empirically. The following four hypotheses concerning members' involvement, trust, satisfaction, and loyalty are formulated:

H1. The membership of a small cooperative is more involved in the governance of the cooperative.

H2: The membership of a small cooperative has more trust in the leadership.

H3: The membership of a small cooperative is more satisfied.

H4: The membership of a small cooperative exhibits stronger loyalty.

\section{STUDY DESIGN}

\subsection{Swedish farm supply and grain marketing industry*}

For conclusions to be drawn from comparisons there should be a number of objects to be compared. The Swedish grain marketing and farm supply industry was thus deemed to be a suitable basis. The industry has 32 registered grain marketing and farm supply cooperatives.

By far the largest cooperative in this industry is Lantmännen, which was established in 2001 after a merger between nine regional cooperatives and the federal organization controlled by these regional cooperatives. Lantmännen operates nationwide. In addition to farmers, its members include 22 local cooperatives and they are not considered in the present investigation.

\footnotetext{
* Data are the latest obtainable in early 2013 unless otherwise stated.
} 
Lantmännen's membership amounts to 36,000 farmers and it has revenues of 38,000 million $\mathrm{SEK}^{\dagger}$ per annum, both figures including local cooperative members. Due to the dominant position of Lantmännen, this cooperative's membership was chosen as one of the data sources.

Apart from the local cooperatives which are affiliated to Lantmännen, there are only a few smaller ones in the Swedish farm supply and grain marketing industry. Four cooperatives are regional and may be considered medium-sized. One of these was chosen as another source of data, namely Varaslättens Lagerhusförening (henceforth only Varaslättens). In 2011 its revenues were 554 million SEK and it had about 1600 members. The three others had revenues between 337 and 1179 million SEK, and their membership was between 831 and 1925. All four operate in regions with good conditions for grain production and pig production.

There are also five independent local cooperatives with membership of between 50 and 200 farmers and revenues of up till a few hundred million SEK. These cooperatives operate within only one village or municipality. One of these cooperatives, namely Södra Åby Lokalförening (henceforth only Södra Åby) was chosen as another source of data. In 2011 it had a membership of 165 and revenues of 145 million SEK.

It is difficult to speak of representativeness. Lantmännen is the only Swedish cooperative in its size category. The four medium-sized cooperatives are similar in some respects. For example, all of them increased their revenues (by 2-18\%) during the last year with available data, all showed good profits, all increased their equity capital (by 4-34\%), and all have a good equity share. It was not possible to make similar comparisons within the group of small and local cooperatives, as they rarely publish their annual reports. Therefore it is unclear to what extent Södra Åby is representative of small cooperatives.

There are also a number of investor-owned firms in the Swedish farm supply and grain marketing industry. The largest of these, with annual revenues of 4000 million SEK, has foreign ownership. It operates in the parts of Sweden with the most intensive crop production. Eleven other firms operate regionally or locally. Their revenues range between 15 and 300 million SEK annually.

\subsection{Data collection}

The data originated from surveys among members of the three selected cooperatives. These cooperatives differ not only in terms of size, but also business orientation (Table 1). However, all supply their members with roughly the same kinds of services.

Lantmännen is one of the largest firms in the Swedish food industry and has extensive nonmember activities. Only $23 \%$ of the cooperative's revenues are member-related. A large part of its business operations comprises far-reaching processing of the members' grain into flour, cereals, bread, ethanol, etc. These downstream activities and the cooperative's foreign operations are organized in four subsidiary companies. Most of these subsidiaries, as well as the cooperative as a whole, are showing declining figures for sales revenues, profits, gross margin, and return on equity capital.

The other two cooperatives deal exclusively with member-related activities. While Lantmännen operates nationwide, the medium-sized Varaslättens works within one region of Western Sweden and the smallest one, Södra ̊̊by, works within one single municipality on the south coast. This means that there is no competition between these two smaller cooperatives, but there is cut-throat competition between Lantmännen and the other two. The three cooperatives pay roughly the same price for members' grain.

\footnotetext{
$\dagger 100$ SEK = approximately 15 USD or 11 EUR.
} 
TABLE 1. Summary of characteristics of the three cooperatives studied ${ }^{1}$

\begin{tabular}{|c|c|c|c|}
\hline Variable & Lantmännen & Varaslättens & Södra Åby \\
\hline Number of members & 36,000 & 1,600 & 165 \\
\hline Revenues $\left(\mathrm{MSEK}^{4}\right)$ & 35,988 & 291 & 147 \\
\hline $\begin{array}{l}\text { Number of countries } \\
\text { with business } \\
\text { operations }\end{array}$ & 18 & 1 & 1 \\
\hline Year of establishment & $2001(1880 \mathrm{~s})^{2}$ & 1930 & 1907 \\
\hline $\begin{array}{l}\text { Annual deliveries } \\
\text { (metric tons) }\end{array}$ & $2,300,000$ & 100,000 & 60,700 \\
\hline $\begin{array}{l}\text { Annual deliveries/ } \\
\text { member (metric tons) }\end{array}$ & 63.8 & 62.5 & 368 \\
\hline $\begin{array}{l}\text { Storage capacity } \\
\text { (metric tons) }\end{array}$ & $2,200,000$ & 125,000 & 34,000 \\
\hline $\begin{array}{l}\text { Revenues per metric } \\
\text { ton }^{3}\left(\mathrm{SEK}^{4}\right)\end{array}$ & 15,648 & 2,328 & 4,324 \\
\hline Number of employees & 10,350 & 27 & 8 \\
\hline Number of directors & 10 & 5 & 8 \\
\hline $\begin{array}{l}\text { Echelons in member } \\
\text { organization }\end{array}$ & $\begin{array}{l}3 \text { ( } 29 \text { wards, } \\
\text { general assembly, } \\
\text { board of directors) }\end{array}$ & $\begin{array}{l}3 \text { (wards, board of } \\
\text { representatives, } \\
\text { board of directors) }\end{array}$ & $\begin{array}{c}2 \text { (general } \\
\text { assembly, board of } \\
\text { directors) }\end{array}$ \\
\hline Net assets $\left(\mathrm{MSEK}^{4}\right)$ & 4,149 & 21 & 19 \\
\hline $\begin{array}{l}\text { Net assets per member } \\
\left(\mathrm{SEK}^{4}\right)\end{array}$ & 115,000 & 13,000 & 115,000 \\
\hline $\begin{array}{l}\text { Participation in the } \\
\text { governing body }\end{array}$ & $3.6 \% 5$ & $15 \%$ & $59 \%$ \\
\hline Business operations & $\begin{array}{l}\text { Grain handling, sales of } \\
\text { farm inputs, milling, } \\
\text { sales of agricultural and } \\
\text { other heavy machinery, } \\
\text { ethanol production, } \\
\text { bakery, food processing, } \\
\text { poultry slaughtering, etc. }\end{array}$ & $\begin{array}{l}\text { Storing, drying, } \\
\text { processing }{ }^{6} \text {, grain } \\
\text { trading, sales of } \\
\text { farm inputs }\end{array}$ & $\begin{array}{l}\text { Storing, drying, } \\
\text { processing }^{6} \text {, grain } \\
\text { trading, sales of } \\
\text { farm inputs and } \\
\text { feed }\end{array}$ \\
\hline
\end{tabular}

${ }^{1}$ Data from the annual reports from 2010 - the latest available when data were collected.

${ }^{2}$ The present cooperative was established through a merger in 2001, but some of the constituent local cooperatives were formed in the 1880 s.

${ }^{3} \mathrm{~A}$ proxy for value-added activities.

${ }^{5}$ Gaurwitsch (2008).

${ }^{6}$ Collecting, drying, cleaning, separating lots (e.g., according to protein content), and mixing.

Data on Lantmännen were collected in 2007, while data on Varaslättens and Södra Åby were collected in 2011. The questionnaires sent to the membership of each cooperative were identical in everything but cooperative name. The findings might have been influenced by the four-year gap between the two data collection periods, during which there may have been some external influences, or some organizational changes. However, surveys conducted regularly by Lantmännen's member relations department concerning member satisfaction with the cooperative indicate that members' opinions about Lantmännen have not changed significantly since 2007 (personal communication with Lantmännen's member relations department officer).

As Lantmännen's membership is large, the sampling procedure took place in two steps. First, the member relations department indicated regions that could be considered representative of the membership as a whole. Two regions were selected, one located in the southernmost province of Sweden, characterized by extensive agriculture and intense competition between 
cooperatives and investor-owned firms; and the other in central Sweden, with rather much agriculture but less intense competition. In each of these regions 300 members were chosen randomly. The aggregated response rate was $40 \%$ after one reminder.

For Varaslättens, the questionnaire was sent to a random sample of 398 out of the total 1600 members. After one reminder, $71 \%$ (284 respondents) returned completed questionnaires. Almost half of the 165 members of Södra A by are passive, i.e., retired farmers. Questionnaires were sent to all 88 farmers who are still active in the opinion of the chairman and the CEO. After one reminder to those who did not return the first questionnaire, a response rate of $72 \%$ (63 respondents) was achieved.

\subsection{Characteristics of the samples}

In all three cases, members aged above 50 dominated, though less so in Varaslättens. Södra Åby and Varaslättens have very specialized memberships, with $95 \%$ and $98 \%$, respectively, of the respondents specializing in crop production, while the figure is $56 \%$ in Lantmännen. The difference is related to the geographical location, i.e., both Varaslättens and Södra Åby operate in crop production areas. The two regions investigated in Lantmännen cover a larger area, which means varying conditions for different types of agricultural production. Therefore, many respondents from Lantmännen produce mainly beef, pork, milk, etc. The respondents in the two smaller cooperatives have larger operations, especially those in Södra Åby (Table 2).

TABLE 2. Member patronage in the three cooperatives

\begin{tabular}{lccc}
\hline $\begin{array}{l}\text { Patronage } \\
(1000 \text { SEK) }\end{array}$ & $\begin{array}{c}\text { Lantmännen } \\
\%(\text { no. })\end{array}$ & $\begin{array}{c}\text { Varaslättens } \\
\%(\text { no. })\end{array}$ & $\begin{array}{c}\text { Södra Åby } \\
\%(\text { no. })\end{array}$ \\
\hline-300 & $23(65)$ & $15(43)$ & $3(2)$ \\
$301-600$ & $13(37)$ & $25(70)$ & $8(5)$ \\
$601-1000$ & $12(34)$ & $19(53)$ & $24(15)$ \\
$1001-1500$ & $12(33)$ & $12(33)$ & $8(5)$ \\
$1501-3000$ & $14(39)$ & $14(40)$ & $27(17)$ \\
$3001-$ & $19(55)$ & $13(38)$ & $29(18)$ \\
No answer & $8(23)$ & $2(6)$ & $2(1)$ \\
\hline Total & $100(286)$ & $100(285)$ & $100(63)$ \\
\hline
\end{tabular}

\subsection{Variables}

The independent variable "size" is a multifaceted construct. It may be expressed as the size of the membership, and thereby also the complexity of the organizational hierarchy. The size of the cooperative's business operations concerns revenues, types of operations, number of employees, geographical region of operations, assets in total and per member, etc. (see Table $1)$.

A number of socioeconomic parameters were examined in the survey. These were farmer's age, experience of being an elected representative in the cooperative, and the member farm's amount of patronage.

The dependent variables represent various dimensions of social capital: member's involvement, trust, satisfaction, and loyalty. Each of these concepts was operationalized into one or more questions in the questionnaire. The answers are in ordinal Likert scales ranging from 1 to 5 . 


\section{Involvement}

- Meeting: It is difficult for me to keep informed about my cooperative's operations, which means that I do not care about attending meetings. (Likert scale from 1, "Do not agree", to 5, "Agree fully")

- Voice: My voice makes a difference. (Likert scale from 1, "Do not agree", to 5, "Agree fully")

- Info: How much do you involve yourself to get information about the cooperative's operations and development? (Likert scale from 1, "Very little", to 5, "Very much")

\section{Trust}

- Board: The board works in the best interests of the members. (Likert scale from 1, "Do not agree", to 5, "Agree fully")

- Rep: I trust the elected representatives. (Likert scale from 1, "Do not agree", to 5, "Agree fully")

\section{Satisfaction}

- Trading: How satisfied are you with your cooperative as a trading partner, i.e., as concerns prices, accessibility, and reception? (Likert scale from 1, "Very dissatisfied" to 5, "Very satisfied")

- Membership: How satisfied are you with your cooperative as a membership organization, i.e., as concerns member activities, information, friendliness, etc.? (Likert scale from 1, "Very dissatisfied", to 5, "Very satisfied")

\section{Loyalty}

- Do you consider yourself to be a loyal member in the sense that you almost always trade with your cooperative, attend meetings, etc.? (Likert scale from 1, "No", to 5, "Yes")

\section{RESULTS}

An ordered logit model is a regression model for dependent variables. It assumes that there is a natural ranking in the possible values of the dependent variable. Considering the inherently ordered nature of the dependent variables (for example, from "Very dissatisfied" to "Very satisfied", or from "Do not agree" to "Agree fully"), an ordered logistic regression was used to untangle the contribution of the size of the cooperative to each aspect of social capital, after controlling for a number of socioeconomic variables. An analysis was run for each aspect of dependent variables. The parameter estimates obtained by using maximum likelihood can be interpreted as the change in log-odds that is associated with a one-unit change in the independent variable. The statistical package SPSS (version 19) was used for these numerical calculations. Table 3 presents the parameter estimates and summarizes the effect of each predictor. All the estimated models that included the independent variables outperformed the null model with the constant only. The figures are available from the authors upon request. All hypotheses were strongly supported by the empirical data. Each of the hypotheses is discussed separately below. 
TABLE 3. Parameter estimates for the ordered logit models for membership social capital

\begin{tabular}{|c|c|c|c|c|c|c|c|c|}
\hline \multirow[b]{3}{*}{ Size $S$} & \multicolumn{3}{|c|}{ Involvement } & \multicolumn{2}{|c|}{ Trust } & \multicolumn{2}{|c|}{ Satisfaction } & \multirow[t]{2}{*}{ Loyalty } \\
\hline & Meeting & Voice & Info & Board & Rep & Trading & Membership & \\
\hline & $-2.19 * *$ & $1.71 * *$ & $1.61 * *$ & $3.29 * *$ & $2.45^{* *}$ & $2.62 * *$ & $3.13^{* *}$ & $1.95 * *$ \\
\hline Size M & $-1.58 * *$ & $1.20 * *$ & $.90 * *$ & $2.93 * *$ & $2.43 * *$ & $2.88 * *$ & $3.15^{* *}$ & $1.11 * *$ \\
\hline Size L & 1 & 1 & 1 & 1 & 1 & 1 & 1 & 1 \\
\hline Revenues & $-.20 * *$ & & $.22 * *$ & & & & & \\
\hline Age & & & & $.20 *$ & $.14^{*}$ & $.33 * *$ & $.24 * *$ & $.20 * *$ \\
\hline Non-rep & $.56^{*}$ & & & $-.58^{*}$ & & & & \\
\hline Rep & 1 & 1 & 1 & 1 & 1 & 1 & 1 & 1 \\
\hline
\end{tabular}

$\backslash$ Reference category

*significant at .05 level, **significant at .01 level

\section{Involvement}

Hypothesis H1 was covered by three questions in the questionnaire. For the first question on "meeting", a positive (negative) estimate indicates a negative (positive) relationship between that predictor and the level of involvement, since a higher score on the dependent variable coincides with a lower level of involvement. First, the negative estimates on "size S" and "size M" indicate that members from the large cooperative are more likely to score high on the first involvement question, that is, "do not care about attending meetings". Second, a higher patronage with a negative coefficient (-.20) corresponds to a decreasing probability of being in one of the "higher" outcome categories, that is, "do not care about attending meetings". Thus the larger the member's patronage, the more likely it is that the member will attend meetings of the cooperative. Third, members who have served as elected representatives in their cooperatives are more likely to care about attending meetings.

A higher score on the second dimension of H1, "voice", indicates a higher level of involvement. The results confirm that members in smaller cooperatives are more likely to feel that their voice makes a difference in the decision making of the cooperative.

The results for the third dimension, "info", prove that member involvement in terms of information gathering is negatively associated with cooperative size and positively associated with members' patronage. That is, members of smaller cooperatives and those with larger patronage are more likely to be in one of the higher categories of "info", i.e., higher involvement in getting "information about the cooperative's operations and development".

Overall for hypothesis H1, there were clear differences in member involvement between the cooperatives of different sizes, and these differences were in full agreement with what was expected, i.e., the members of the large cooperative were less involved. This applied for all the parameters used to determine involvement, i.e., attendance at meetings, influence, and information gathering in general. Moreover, the greater coefficients on "size $S$ " than on "size M" indicate a greater probability of the small cooperative's members having higher involvement than the medium-sized cooperative's members.

\section{Trust}

Hypothesis H2 was assessed with the help of two questions, one expressing the members' perception of board work and the other asking specifically about their trust in the representatives. The responses to both questions provided strong support for the hypothesis.

Two-thirds (67\%) of the respondents from Södra Åby reported that they appreciated the work of the board, while $56 \%$ of the Varaslättens respondents and only $8 \%$ of Lantmännen respondents agreed fully. As Table 3 shows, members were more likely to trust the board if they belonged to a small or medium-sized cooperative, had been an elected representative, or were older. 
The percentage of members reporting that they fully trusted the elected representatives was $56 \%, 53 \%$, and $13 \%$ for Södra Åby, Varaslättens, and Lantmännen, respectively, i.e., the differences were as pronounced as those relating to trust in the board, although not quite as large. The results showed that older members, as well as members from smaller cooperatives, were more likely to trust the elected representatives. Again, the greater coefficients on "size S" than that on "size M" suggested that members of the small cooperative are more likely to trust the board and representatives than members of the medium-sized cooperative.

\section{Satisfaction}

As concerns member satisfaction (hypothesis H3), older members and members of small and medium-sized cooperatives were more likely to be satisfied with their cooperatives, both as a trading partner and as a membership organization. However, the greater coefficients on "size $\mathrm{M}$ " than that on "size $S$ " indicate a larger probability of members of the medium-sized cooperative being more satisfied than members of the small cooperative.

\section{Member loyalty}

Hypothesis H4 was also strongly supported. Members of the large cooperative were found to be less loyal to their cooperative than members of small and medium-sized cooperatives, and members of the small cooperative were more likely to score high on loyalty than members of the medium-size cooperative. Among the respondents from the smallest cooperative, $44 \%$ agreed fully that they are loyal, while $19 \%$ of respondents from the medium-sized cooperative and $13 \%$ of those from the largest cooperative did so. Compared with the other questions, these responses were more evenly distributed between "no loyalty" and "great loyalty", indicating heterogeneity in member opinions when it comes to loyalty. It was also found that older members were more likely to be highly loyal to the cooperative in terms of trading and attending meetings.

\section{DISCUSSION}

The results strongly support all four hypotheses, indicating that the smallest cooperative has higher social capital among its membership than the medium-sized cooperative, which in turn has higher social capital than the largest cooperative. The four social capital components together form a system of attributes that are aligned in order to bring their interdependencies and synergies to value (Milgrom \& Roberts, 1990).

The present study focuses on cooperatives of different sizes. Size is interdependent with other organizational attributes, so it is impossible to isolate them from each other. However, there are arguments that the findings would be similar if other attributes had been investigated, such as geographical coverage, legal demands, business strategies, and organizational principles. Each of these four factors is discussed below to explain the differences between the three cooperatives.

\section{Geographical coverage}

The membership of the small and the medium-sized cooperative is relatively homogeneous. The business scope of both the members and these two cooperatives is strictly defined, as they are operating within regions with intensive grain production and thus focus on grain handling. The large cooperative in this study has operations throughout Sweden, spanning different climate conditions, crops, types of soil, farm acreages, etc. Its membership is thus extremely heterogeneous, so it cannot focus on specific member categories and specific business lines. 


\section{Legal demands}

The Swedish legislation on cooperatives demands open membership. Cooperatives have to accept all farmers who want to be members. This requirement is especially demanding for a cooperative that is dominant and nationwide. The open membership policy means that Lantmännen has a membership that demands a wide spectrum of goods and services. Therefore Lantmännen cannot exploit effects of scale and scope to the extent expected on the basis of its aggregate size. The Swedish legislation on competition protection does not require cooperatives to accept membership applications from outside the geographical area they have defined for themselves, rendering small cooperatives' membership more homogeneous.

Another legal requirement concerns equal treatment of members. There are limitations concerning price and service differentiation for cooperatives. Lantmännen is obliged to offer the same conditions to the large farms in the fertile regions of Sweden, where there is intense competition, and to the small farms in forest regions, where competition is weak. Market segmentation is also impossible from a membership policy perspective. The two smaller cooperatives can easily adapt to the conditions, as they operate in small, homogeneous market segments.

\section{Business strategy}

The three cooperatives follow different strategies. While the two smaller cooperatives operate solely with member-related businesses, Lantmännen has vertically integrated operations and non-member related businesses, as well as foreign subsidiaries. As non-member-related activities make up more than three-quarters of its operations, members have lost much interest in the cooperative (Kihlén, 2007). Only four per cent of Lantmännen's members read the annual report carefully (Gaurwitsch \& Nilsson, 2010, p. 10). Another study of this cooperative concluded that the members "do not believe that the cooperative can be remodeled to strengthen the member control" (Nilsson, Kihlén \& Norell, 2009, p. 103).

\section{Organizational principles}

The cooperatives adhere to different organizational principles. Both Södra Åby and Varaslättens are organized and financed fully in accordance with traditional cooperative principles. Over the decades both have received several merger proposals, but they have abstained from expanding horizontally or vertically.

In contrast, Lantmännen has followed a route of expansion, which has created VDPR problems. In an attempt to remedy these problems, new organizational principles have been introduced in recent years. The Board of Directors has introduced some measures to create alignment between residual claimant rights and control rights, i.e., to obtain transparency in the members' roles as patrons and investors. The member-related business and the non-memberrelated businesses have become organizationally and financially separated. The member-related operations are run according to a business-at-cost principle, and the members control these operations in their role as patrons. They usually receive high patronage refunds. The nonmember operations are profit-maximizing subsidiaries. In their role as owners, the members receive competitive dividends for their investments in the cooperative. The members are also invited to buy preferred stock to be invested in the subsidiaries, and part of the profits from the subsidiaries is paid as dividends. The preferred stock is freely tradable and appreciable. Lantmännen redeems its retained patronage funds through revolving funds, which are also tradable and appreciable. However, these financial solutions have not been very popular within the membership (Karlsson, 2010).

As the discussion above indicates, the four dimensions of social capital are related not only to the cooperative size, but also to other attributes of the firms such as their geographical coverage, legal framework, market strategies and organizational principles. Due to the 
interrelations between the various attributes, there are distinct systems, which display different levels of social capital among members. Hence the findings of this study are more broadly applicable and would probably have been similar had any of the other attributes been analyzed.

\section{CONCLUSIONS}

The basic assumption behind this study was that social capital is negatively associated with cooperative size. The empirical data obtained from the members of three cooperatives of widely varying size strongly support this assumption. However, it is uncertain to what extent the findings can be generalized, as this study only compares three cooperatives within one industry in one country. Comparisons between different countries and industries would be desirable, but such data would be difficult to interpret.

There are theoretical explanations for the differences observed in members' social capital between cooperatives of different sizes. A cooperative with a focused strategy most likely has a small, homogeneous membership, so the members may have the same interests, communicate with each other, meet the leadership, etc., i.e., there may be strong involvement within the membership. A focused strategy also means that the cooperative's business operations concern the members, who thereby remain interested in what happens to their agricultural products after they leave the farm gate.

When a cooperative expands, members become detached and unable to exert much influence. The fact that cooperatives with far-reaching horizontal and vertical integration may be more efficient, due to economies of scale, does not seem to result in higher social capital within the membership. Once a cooperative begins replicating the strategies of investor-owned firms, the members no longer feel associated with it.

\section{REFERENCES}

Bager, T. (1996). Organisations in sectors. Explaining the dissemination of populations of formal organization in economic sectors - bridging rational choice and institutional approaches. Esbjerg, Denmark: South Jutland University Press.

Barbaud-Didier, V., Henninger, M.-C., \& El Akremi, A. (2012). The relationship between members' trust and participation in the governance of cooperatives: The role of organizational commitment. International Food and Agribusiness Management Review, 15(1), 1-24.

Bhuyan, S. (2007). The people factor in cooperatives: an analysis of members' attitudes and behavior. Canadian Journal of Agricultural Economics, 55(3), 275- 298.

Borgen, S.O. (2001). Identification as a trust-generating mechanism in cooperatives, Annals of Public and Cooperative Economics, 72(2), 209-228.

Bourdieu, P. (1986). The forms of capital. In J.G. Richardson (Ed.) Handbook of theory and research for the sociology of education (pp. 241-258). New York, NY: Greenwood Press.

Bravo-Ureta, B.E. \& Lee, T.C. (1988). Socioeconomic and technical characteristics of New England dairy cooperative members and non-members. Journal of Agricultural Cooperation, $3,12-27$.

Brazda, J. \& Schediwy, R. (Ed.) (1989). Consumer co-operatives in a changing world. Geneva, Switzerland: International Co-operative Alliance.

Burt, L. \& Wirth. M.E. (1990). Assessing the effectiveness of a farm supply cooperative: A comparison of farmer and manager viewpoints. Journal of Agricultural Cooperatives, 5, $17-$ 26. 
Cain, J.L., Toensmeyer, U.C., \& Ramsey, S. (1989). Cooperative and proprietary firm performance as viewed by their customers. Journal of Agricultural Cooperation, 4, 81-88.

Cook, M.L. (1995). The future of U.S. agricultural cooperatives: A neo-institutional approach. American Journal of Agricultural Economics, 77(5), 1153-1159.

Fulton, J.R. \& Adamowicz, W.L. (1993). Factors that influence the commitment of members to their cooperative organization. Journal of Agricultural Cooperatives, 8, 39-53.

Fulton, M.E. \& Hueth, B. (2009). Cooperative conversions, failures and restructurings: an overview. Journal of Cooperatives, 23: i-xi.

Gaurwitsch, S. \& Nilsson, J. (2010). Members' readership of annual reports - A cross-national comparison of supply co-operatives, Journal of Co-operative Studies, 43(1), 5-13.

Gaurwitsch, S. (2008). Årsredovisningen i kooperativa föreningar. Läser medlemmarna Lantmännens årsredovisning? (The annual report in cooperative societies. Do members read Lantmännen's annual report?) Uppsala, Sweden: Department of Economics, Swedish University of Agricultural Sciences (Master thesis 522, with a summary in English).

Gray, T.W. \& Kraenzle, C.A. (1998). Member participation in agricultural cooperatives: A regression and scale analysis. Research report 165 . Rural business-cooperative service. Washington, DC: United States Department of Agriculture.

Hakelius, K. (1996). Cooperative values. Farmers' cooperatives in the minds of the farmers. PhD Dissertation 23. Uppsala, Sweden: Swedish University of Agricultural Sciences.

Hansen, M.H., Morrow Jr., J.L. \& Batista, J.C. (2002). The impact of trust on cooperative membership retention, performance, and satisfaction: an exploratory study. International Food and Agribusiness Management Review, 5(1), 41-59.

Hansmann, H. (1996). The ownership of enterprise. Cambridge, MA: The Belknap Press.

Harte, L.N. (1997). Creeping privatisation of Irish co-operatives. A transaction cost explanation. In J. Nilsson and G. Van Dijk (Ed.) Strategies and structures in the agro-food industries (pp. 31-53). Assen, Netherlands: Van Gorcum.

Hendrikse, G.W.J. \& Feng, L.. (2013). Interfirm cooperatives. In handbook of economic organization; integrating economic and organizational theory, edited by A. Grandori, 501521). Cheltenham, UK: Edward Elgar,

Hind, A.M. (1999). Co-operative life cycle and goals. Journal of Agricultural Economics, 50, $536-548$.

Hogeland, J.A. (2006). The economic culture of U.S. agricultural cooperatives. Culture and Agriculture, 28(2), 67-79.

Ilmonen, K. (1992). The end of cooperative movement. Helsinki, Finland: Labour Institute of Economic Research.

James Jr., H.S. \& Sykuta, M.E. (2005). Property right and organizational characteristics of producer-owned firms and organizational trust. Annals of Public and Cooperative Economics, 76(4), 545-580.

James Jr., H.S. \& Sykuta, M.E. (2006). Farmer trust in producer- and investor-owned firms: Evidence from Missouri corn and soybean producers. Agribusiness: An International Journal, 22(1), 135-153.

Jensen, K. (1990). Factors associated with the selection of cooperative vs. proprietary handlers of milk in Tennessee. Journal of Agricultural Cooperation, 5, 27-35.

Karantininis, K. and Zago, A.. (2001). Endogenous membership in mixed duopsonies. American Journal of Agricultural Economics, 83(5), 1266-1272.

Karlsson, O. (2010). Lantmännens emission av förlagsandelar och handeln med emissionsinsatser - En analys av medlemmarnas motiv till beslut. (The issuance of B-shares and the trade with bonus shares in Swedish Farmers' Supply and Crop Marketing Association - an analysis of members' motives). Uppsala, Sweden: Department of 
Economics, Swedish University of Agricultural Sciences (Master thesis 588, with a summary in English).

Kihlén, A. (2007). Lantmännens nya medlemsorganisation - utvärdering ur ett medlemsperspektiv. (The new membership organisation of the Swedish Farmers' Supply and Crop Marketing Association - an evaluation from a member perspective). Uppsala, Sweden: Department of Economics, Swedish University of Agricultural Sciences (Master thesis 487, with a summary in English).

King, R.P. (1995). The future of agricultural cooperatives in North America: Discussion. American Journal of Agricultural Economics, 77(5), 1160-1161.

Klein, K.K., Richards, T.J. \& Walburger, A. (1997). Determinants of co-operative patronage in Alberta. Canadian Journal of Agricultural Economics, 45(2), 93-110.

Lamprinakis, L. \& Fulton, M.E. (2011). Does acquisition of a cooperative generate profits for the buyer? The Dairyworld case. Agricultural Economics, 42 (Supplement), 89-100.

Lang, K.A. \& Fulton, M.E. (2004). Member commitment and the market and financial performance of the Saskatchewan wheat pool. Current Agriculture, Food and Resource Issues, 5, 238-252.

Lind, L.W., \& Åkesson, E. (2005). Pig producers' choice of slaughterhouse - co-operative or investor-owned? International Journal of Co-operative Management, 2(2), 40-46.

Michels, R. (2001 [1911]). Political parties. A sociological study of the oligarchical tendencies of modern democracy. Kitchener, Ontario: Batoch.

Milgrom, P. \& Roberts, J. (1990). The economics of modern manufacturing: Technology, strategy and organization. American Economic Review, 80(3), 511-528.

Misra, S.K., Carley D.H. \& Fletcher, S.M. (1993). Dairy farmers' evaluation of dairy cooperatives. Agribusiness: An International Journal, 9(4), 351-361.

Morrow Jr., J.L., Hansen, M.H. \& Pearson, A.W. (2004). The cognitive and affective antecedents of general trust within cooperative organizations. Journal of Managerial Issues, $16(1), 48-64$.

Nilsson, J. \& Svendsen, G.T. (2011), Free riding or trust? Why members (do not) monitor their co-operatives. Journal of Rural Cooperation, 39 (2), 131-150.

Nilsson, J. (1998). The emergence of new organizational models for agricultural cooperatives. Swedish Journal of Agricultural Research, 28, 39-47.

Nilsson, J. (2001). Organisational principles for cooperative firms. Scandinavian Journal of Management, 17(3), 329-356.

Nilsson, J., Kihlén, A. \& Norell, L. (2009). Are traditional cooperatives an endangered species? About shrinking satisfaction, involvement and trust. International Food and Agribusiness Management Review, 12(4), 103-123.

Nilsson, J., Svendsen, G.L.H., \& Svendsen G.T. (2012). Are large and complex agricultural cooperatives losing their social capital? Agribusiness: An International Journal, 28(2), 187204.

Ollila, P. (1989). Coordination of supply and demand in the dairy marketing system - with special emphasis on the potential role of farmer cooperatives as coordinating institutions. Journal of Agricultural Science in Finland, 61(3), 135-322.

Österberg, P. \& Nilsson, J. (2009). Members' perception of their participation in the governance of cooperatives: The key to trust and commitment in agricultural cooperatives. Agribusiness: An International Journal, 25(2), 181-197.

Richards, T.J, Klein K.K., \& Walburger, A. (1998). Principal-agent relationships in agricultural cooperatives: An empirical analysis from rural Alberta. Journal of Cooperatives, 13, 21-33.

Sexton, R.J. (1986). The formation of cooperatives: A game-theoretic approach with implications for cooperative finance, decision making, and stability. American Journal of Agricultural Economics, 68(2), 214-225. 
Staatz, J.M. (1987). Farmers' incentives to take collective action via cooperatives: a transaction cost approach. In Cooperative Theory, New Approaches. USDA, ACS Service Report 18 (pp. 87-108).

Wadsworth, J.J. (1991). An analysis of major farm characteristics and farmers' use of cooperatives. Journal of Agricultural Cooperatives, 6, 45-53.

Woolcock, M. (1998). Social capital and economic development: Towards a theoretical synthesis and policy framework. Theory and Society, 27, 151-208.

Zeuli, K. \& Betancor, A. (2005, November). The effects of cooperative competition on member loyalty. Paper presented at the NCERE-194 2005 Annual Meeting, Minneapolis, MN, USA.

Li Feng is a research associate at Swedish University of Agricultural Sciences, Uppsala, Sweden. She earned her PhD in management in 2010 from Rotterdam School of Management, Erasmus University, the Netherlands. Her research interests are economics of organizations, with a special interest in cooperatives.

Anna Friis is a manager in Sweden's largest cooperative mortgage bank for agriculture and silviculture. She earned her MSc in Agricultural Economics in 2011 from Swedish University of Agricultural Sciences, Uppsala, Sweden.

Jerker Nilsson is a professor of cooperative business and marketing at Swedish University of Agricultural Sciences, Uppsala, Sweden. He earned his PhD in marketing in 1980 from Lund University, Sweden. His current research interests are structural changes in agrifood industries and, organizational models for agricultural cooperatives. 